\title{
Synthesis, Crystal Structure, Spectroscopic Characterization, DFT Calculations and Cytotoxicity Assays of a New Cu(II) Complex with an Acylhydrazone Ligand Derived from Thiophene
}

\author{
María R. Rodríguez ${ }^{1}\left(\right.$, Lucía M. Balsa $^{1}$, Oscar E. Piro ${ }^{2}{ }^{\circledR}$, Gustavo A. Etcheverría ${ }^{2}$, Javier García-Tojal ${ }^{3}{ }^{(0)}$, \\ Reinaldo Pis-Diez ${ }^{1}{ }^{\circledR}$, Ignacio E. León ${ }^{1}$, Beatriz P. Parajón-Costa ${ }^{1}$ and Ana C. González-Baró ${ }^{1, *}$ \\ 1 CEQUINOR (CONICET-CCT La Plata-UNLP), Bvd. 120 N$^{\circ} 1465$, B1900AVV La Plata, Argentina; \\ mariarosar@quimica.unlp.edu.ar (M.R.R.); luciambalsa@gmail.com (L.M.B.); \\ pis_diez@quimica.unlp.edu.ar (R.P.-D.); ileon@biol.unlp.edu.ar (I.E.L.); \\ beatrizp@quimica.unlp.edu.ar (B.P.P.-C.) \\ 2 IFLP (CONICET-CCT La Plata-UNLP), CC 67, B1900AVV La Plata, Argentina; piro@fisica.unlp.edu.ar (O.E.P.); \\ geche@fisica.unlp.edu.ar (G.A.E.) \\ 3 Department de Química-UBU, Pza. Misael Bañuelos s/n, E-09001 Burgos, Spain; qipgatoj@ubu.es \\ * Correspondence: agb@quimica.unlp.edu.ar
}

\section{check for}

updates

Citation: Rodríguez, M.R.; Balsa, L.M.; Piro, O.E.; Etcheverría, G.A.; García-Tojal, J.; Pis-Diez, R.; León, I.E.; Parajón-Costa, B.P.; González-Baró, A.C. Synthesis, Crystal Structure, Spectroscopic Characterization, DFT Calculations and Cytotoxicity Assays of a New $\mathrm{Cu}$ (II) Complex with an Acylhydrazone Ligand Derived from Thiophene. Inorganics 2021, 9, 9. https://doi.org/10.3390/inorganics 9020009

Received: 11 December 2020

Accepted: 11 January 2021

Published: 20 January 2021

Publisher's Note: MDPI stays neutral with regard to jurisdictional claims in published maps and institutional affiliations.

Copyright: (c) 2021 by the authors. Licensee MDPI, Basel, Switzerland. This article is an open access article distributed under the terms and conditions of the Creative Commons Attribution (CC BY) license (https:// creativecommons.org/licenses/by/ $4.0 /)$.

\begin{abstract}
A new $\mathrm{Cu}(\mathrm{II})$ complex is synthetized by the reaction of copper nitrate and a $\mathrm{N}$-acylhydrazone ligand obtained from the condensation of $o$-vanillin and 2-thiophecarbohydrazide $\left(\mathrm{H}_{2} \mathrm{~L}\right)$. The solidstate structure of $\left[\mathrm{Cu}(\mathrm{HL})\left(\mathrm{H}_{2} \mathrm{O}\right)\right]\left(\mathrm{NO}_{3}\right) \cdot \mathrm{H}_{2} \mathrm{O}$, or CuHL for simplicity, was determined by X-ray diffraction. In the cationic complex, the copper center is in a nearly squared planar environment with the nitrate interacting as a counterion. CuHL was characterized by spectroscopic techniques, including solid-state FTIR, Raman, electron paramagnetic resonance (EPR) and diffuse reflectance and solution UV-Vis electronic spectroscopy. Calculations based on the density functional theory (DFT) assisted the interpretation and assignment of the spectroscopic data. The complex does not show relevant antioxidant activity evaluated by the radical cation of 2,2'-azinobis(3-ethylbenzothiazoline6-sulfonic acid) diammonium salt (ABTS) method, being even less active than the free ligand as a radical quencher. Cytotoxicity assays of CuHL against three human tumor cell lines, namely MG-63, A549 and HT-29, revealed an important enhancement of the effectiveness as compared with both the ligand and the free metal ion. Moreover, its cytotoxic effect was remarkably stronger than that of the reference metallodrug cisplatin in all cancer cell lines tested, a promissory result in the search for new metallodrugs of essential transition metals.
\end{abstract}

Keywords: copper(II) complex; $N$-acylhydrazone; spectroscopy; XRD crystal structure; DFT calculations; anti-cancer activity

\section{Introduction}

Copper(II) is associated to systems involved in biological processes such as oxygen or electron transport [1]. Due to its low redox potential, it can participate in oxidative enzymatic reactions, being one of the essential metal ions in metabolic processes of the human organism [2]. In addition to cellular respiration, this metal is involved in the formation of pigments, the biosynthesis of neurotransmitters and the formation of connective tissue, among other processes [3,4].

Copper coordination chemistry has gained importance as many compounds showed interesting chemical and therapeutic properties such as catalytic, analytical, antibacterial, anti-inflammatory and anti-proliferative properties of tumor cells, enhancing the activity of the respective free ligands [5-12].

Among the broad diversity of organic ligands with relevant properties, copper coordination compounds with Schiff bases (SB) were reported. SBs are a family of compounds characterized by the presence of the azomethine group in their chemical structure. They 
are of interest in a variety of application fields, including analytical, biological and inorganic chemistry. In recent decades, they have acquired importance in medicine and pharmacology due to their anti-inflammatory, analgesic, anti-microbial, anti-convulsant, anti-tuberculosis, anti-tumor and antioxidant activity, among other properties [13-20]. $\mathrm{N}$-acylhydrazones constitute a particularly interesting group included in the BS family. The presence of the $[\mathrm{O}=\mathrm{C}(\mathrm{R})-\mathrm{NH}-\mathrm{N}=\mathrm{C}<]$ function and their structural characteristics provide high stability and special properties to the molecule. Acting as ligands, they lead to the formation of coordination compounds with biological activity [21-23]. Particularly, the compound 2-acetylthiophene-2-hydroxy-3-methoxybenzohydrazone monohydrate, previously named $o$-HVATPNNH and hereafter referred to as $\mathrm{H}_{2} \mathrm{~L}$, has been previously synthesized and structurally characterized [24] and has the conditions of an effective ligand. The precursors used to obtain the ligand were selected taking into account that (i) $o$-vanillin (3-methoxysalicilaldehyde or 2-hydroxy-3-methoxybenzaldehyde) showed antioxidant activity, low toxicity and strong tendency to combine with amine derivatives, generating stable ligands $[23,25,26]$, and that (ii) thiophene (five-membered heterocyclic with sulfur as the heteroatom) and its derivatives have been widely studied for their therapeutic applications $[27,28]$, showing good results as anti-tumor agents $[29,30]$, analgesic and anti-inflammatory [31], anti-hypertensive [32], anti-diabetic [33], cholesterol activity inhibitors [34], anti-allergenic [35] and antioxidant agents [36], constituting a group of compounds of both pharmacological and agrochemical interest for their bactericidal, fungicidal and herbicidal activity.

In this work, we report the synthesis of a $\mathrm{Cu}$ (II) complex obtained by the reaction of a salt of this metal and the $\mathrm{H}_{2} \mathrm{~L}$ ligand, hereafter named CuHL for short, and discuss its characterization, including crystal structure determination, spectroscopic analysis and density functional theory (DFT) calculations, together with its antioxidant effect and cytotoxic activity against a panel of human cancer cells. Promissory results have been achieved in the search for new therapeutic agents of essential transition metals having less toxicity than the reference platinum metallodrugs.

\section{Results and Discussion}

\subsection{Syntheses}

The ligand $\mathrm{H}_{2} \mathrm{~L}$ was prepared according to the reported procedure [24]. To obtain the complex, an ethanolic solution of $\mathrm{H}_{2} \mathrm{~L}$ was added to a solution of copper (II) salt in the same solvent, according to the reaction depicted in Scheme 1. The reaction was held under stirring and mild heating conditions, and dark green crystals of the complex were obtained from the solution after some weeks. More details can be found in the Experimental section.

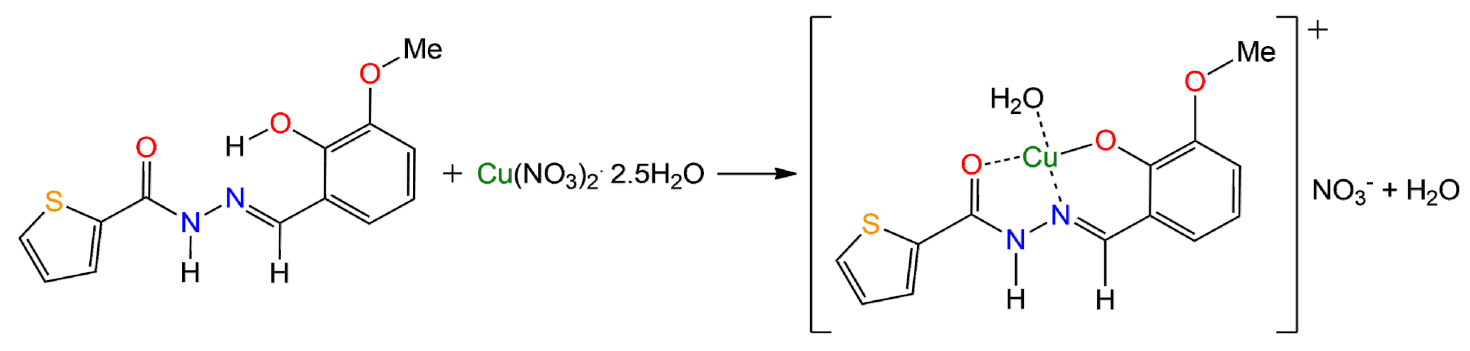

Scheme 1. Synthesis of the complex $\left[\mathrm{Cu}(\mathrm{HL})\left(\mathrm{H}_{2} \mathrm{O}\right)\right]\left(\mathrm{NO}_{3}\right) \cdot \mathrm{H}_{2} \mathrm{O}(\mathrm{CuHL})$.

\subsection{Crystal Structure}

Crystal data and structure refinement results for $\left[\mathrm{Cu}(\mathrm{HL})\left(\mathrm{H}_{2} \mathrm{O}\right)\right]\left(\mathrm{NO}_{3}\right) \cdot \mathrm{H}_{2} \mathrm{O}$ are listed in Table 1. Figure 1 shows an Oak Ridge Thermal Ellipsoid Plot (ORTEP) [37] plot of the solid-state molecule, and selected bond distances and angles are listed in Table 2. 
Table 1. Crystal data and structure refinement of CuHL.

\begin{tabular}{|c|c|}
\hline Empirical formula & $\mathrm{C}_{13} \mathrm{H}_{15} \mathrm{CuN}_{3} \mathrm{O}_{8} \mathrm{~S}$ \\
\hline Formula weight & 436.88 \\
\hline Temperature & 293(2) K \\
\hline Wavelength & $1.54184 \AA$ \\
\hline Crystal system & Triclinic \\
\hline Space group & P-1 \\
\hline \multicolumn{2}{|l|}{ Unit cell dimensions } \\
\hline $\mathrm{a}$ & $9.3380(5) \AA$ \\
\hline $\mathrm{b}$ & $9.6015(5) \AA$ \\
\hline c & $11.3991(7) \AA$ \\
\hline$\alpha$ & $97.334(5)^{\circ}$ \\
\hline$\beta$ & $104.595(5)^{\circ}$ \\
\hline $\mathrm{r}$ & $116.924(5)^{\circ}$ \\
\hline Volume & $846.52(8) \AA^{3}$ \\
\hline Z, density (calculated) & $2,1.714 \mathrm{Mg} / \mathrm{m}^{3}$ \\
\hline Absorption coefficient & $3.442 \mathrm{~mm}^{-1}$ \\
\hline $\mathrm{F}(000)$ & 446 \\
\hline$\theta$-range for data collection & 4.17 to $72.41^{\circ}$ \\
\hline Index ranges & $-9 \leq \mathrm{h} \leq 11,-11 \leq \mathrm{k} \leq 9,-14 \leq 1 \leq 13$ \\
\hline Reflections collected & 7440 \\
\hline Independent reflections & $3335[\mathrm{R}(\mathrm{int})=0.023]$ \\
\hline Observed reflections $[\mathrm{I}>2 \sigma(\mathrm{I})]$ & 2989 \\
\hline Completeness to $\theta=72.41^{\circ}$ & $99.4 \%$ \\
\hline Refinement method & Full-matrix least-squares on $\mathrm{F}^{2}$ \\
\hline Data/restraints/parameters & $3335 / 6 / 252$ \\
\hline Goodness-of-fit on $\mathrm{F}^{2}$ & 1.047 \\
\hline Final $\mathrm{R}$ indices $[\mathrm{I}>2 \sigma(\mathrm{I})]$ & $\mathrm{R} 1=0.0449, \mathrm{wR} 2=0.1264$ \\
\hline $\mathrm{R}$ indices (all data) & $\mathrm{R} 1=0.0496, \mathrm{wR} 2=0.1323$ \\
\hline Largest diff. peak and hole & 0.641 and -0.555 e. $\AA^{-3}$ \\
\hline
\end{tabular}

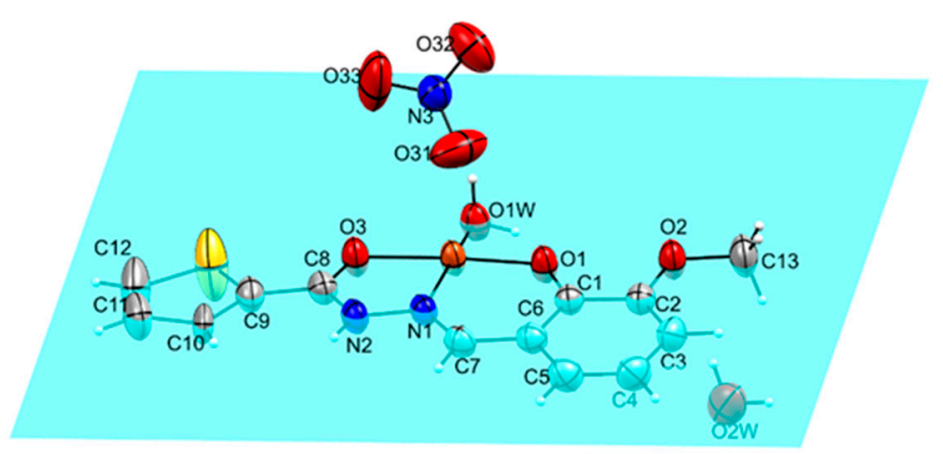

Figure 1. Drawing of CuHL showing the labeling of the non-H atoms and their displacement ellipsoids at the $30 \%$ probability level and the planarity of the coordination environment.

The cationic complex crystallizes with the $\mathrm{Cu}(\mathrm{II})$ ion at the center of a nearly square environment, coordinated by the $\mathrm{HL}^{-}$anion (by loss of the phenolic proton) acting as a tridentate ligand through the phenolic oxygen $[\mathrm{d}(\mathrm{Cu}-\mathrm{O})=1.885(3) \AA]$, the imine nitrogen $[\mathrm{d}(\mathrm{Cu}-\mathrm{N})=1.927(2) \AA]$ and the carbonyl oxygen $[\mathrm{d}(\mathrm{Cu}-\mathrm{O})=1.978(3) \AA]$ and by a water molecule $[\mathrm{d}(\mathrm{Cu}-\mathrm{Ow})=1.953(2) \AA]$. The metal is capped by one oxygen atom of the nitrate counterion at a contact distance of $2.429(5) \AA$.

The crystal is further stabilized by a net of intermolecular H-bonds involving, as donors, the $\mathrm{HL}^{-}$amine group and the water molecules (w1 and $\mathrm{w} 2$ ) and, as acceptors, the crystallization water molecule (w2) and the nitrate and $\mathrm{HL}^{-}$methoxy and carbonyl oxygen atoms. The H-bonding structure is detailed in Table S1 of the Supplementary Materials. In the crystal packing (Figure S1), the layered arrangement of the cationic complexes can be appreciated. 
Table 2. Selected experimental and calculated geometric parameters of CuHL.

\begin{tabular}{|c|c|c|c|c|c|}
\hline \multicolumn{3}{|c|}{ Bond Distances (̊̊) } & \multicolumn{3}{|c|}{ Bond Angles $\left({ }^{\circ}\right)$} \\
\hline & Exp. & Calc. & & Exp. & Calc. \\
\hline $\mathrm{Cu}-\mathrm{N} 1$ & 1.927 & 1.957 & $\mathrm{~N} 1-\mathrm{Cu}-\mathrm{O} 3$ & 81.6 & 79.4 \\
\hline $\mathrm{Cu}-\mathrm{O} 1$ & 1.885 & 1.915 & $\mathrm{Cu}-\mathrm{N} 1-\mathrm{N} 2$ & 111.7 & 112.1 \\
\hline $\mathrm{Cu}-\mathrm{O} 1 \mathrm{~W}$ & 1.953 & 1.990 & $\mathrm{~N} 1-\mathrm{Cu}-\mathrm{O} 1$ & 92.8 & 91.1 \\
\hline $\mathrm{Cu}-\mathrm{O} 3$ & 1.978 & 2.094 & $\mathrm{O} 1-\mathrm{Cu}-\mathrm{O} 3$ & 174.4 & 161.8 \\
\hline $\mathrm{Cu}-\mathrm{O} 31$ & 2.429 & 2.257 & $\mathrm{O} 1 \mathrm{~W}-\mathrm{Cu}-\mathrm{N} 1$ & 167.8 & 173.0 \\
\hline O1-C1 & 1.311 & 1.285 & $\mathrm{O} 1 \mathrm{~W}-\mathrm{Cu}-\mathrm{O} 1$ & 92.4 & 94.5 \\
\hline N1-C7 & 1.290 & 1.297 & $\mathrm{~N} 1-\mathrm{Cu}-\mathrm{O} 31$ & 98.0 & 92.3 \\
\hline N1-N2 & 1.376 & 1.374 & $\mathrm{O} 3-\mathrm{Cu}-\mathrm{O} 1 \mathrm{~W}$ & 93.1 & 94.0 \\
\hline C8-N2 & 1.342 & 1.354 & $\mathrm{O} 3-\mathrm{Cu}-\mathrm{O} 31$ & 96.6 & 89.2 \\
\hline $\mathrm{C} 8-\mathrm{O} 3$ & 1.258 & 1.247 & $\mathrm{O} 1-\mathrm{Cu}-\mathrm{O} 31$ & 84.2 & 106.9 \\
\hline O31-N3 & 1.217 & 1.272 & $\mathrm{O} 1 \mathrm{~W}-\mathrm{Cu}-\mathrm{O} 31$ & 93.6 & 90.2 \\
\hline $\mathrm{C} 2-\mathrm{O} 2$ & 1.365 & 1.353 & N3-O31-Cu & 136.4 & 127.0 \\
\hline $\mathrm{O} 2-\mathrm{C} 13$ & 1.420 & 1.416 & & & \\
\hline N3-O32 & 1.212 & 1.275 & \multicolumn{3}{|c|}{ Dihedral Angles $\left({ }^{\circ}\right)$} \\
\hline N3-O33 & 1.217 & 1.216 & & Exp. & Calc. \\
\hline \multirow[t]{6}{*}{$\mathrm{C} 6-\mathrm{C} 7$} & 1.430 & 1.417 & O3-Cu-N1-N2 & -1.5 & -9.8 \\
\hline & & & N1-Cu-O1-C1 & 5.8 & -10.8 \\
\hline & & & $\mathrm{O} 3-\mathrm{C} 8-\mathrm{C} 9-\mathrm{S}$ & 4.9 & -10.2 \\
\hline & & & O3-C8-N2-N1 & -1.6 & 1.4 \\
\hline & & & O2-C2-C1-O1 & 0.9 & 0.0 \\
\hline & & & N2-C8-C9-S & -174.0 & 170.3 \\
\hline
\end{tabular}

The copper complexes can be considered as monomeric species (the nearest copper metal ions in the crystal are $4.921 \AA$ apart), with no appreciable $\mathrm{Cu}-\mathrm{Cu}$ exchange interaction taking place in the lattice.

Due to the coordination of the tridentate ligand with the $\mathrm{Cu}$ (II) ion, two coordination rings are formed, one of five and the other of six members, which promote the planarity of the environment, as can be seen in Figure 1.

Geometry optimizations were carried out using the experimental structure as a starting point and within the framework of the DFT. As the nitrate anion is a counterion, it was not considered in a first set of calculations. However, the results of those calculations indicated that the metal ion coordination sphere deviates from the planarity. A second set of calculations, including the nitrate ion, allows the complex to recover its planar coordination around the metal ion. Thus, the final optimized structure used to obtain structural and spectroscopic properties contains the nitrate ion.

Table 2 compares the experimental and calculated values for selected structural parameters. It can be seen in the table that the agreement is very good, especially for dihedral angles that determine the spatial conformation of the complex. The experimental and the calculated structures are superimposed in Figure 2, making clear the goodness of the optimized geometry. Tables S5-S7 provide an extensive list of the calculated bond distances, bond angles and dihedral angles, respectively.

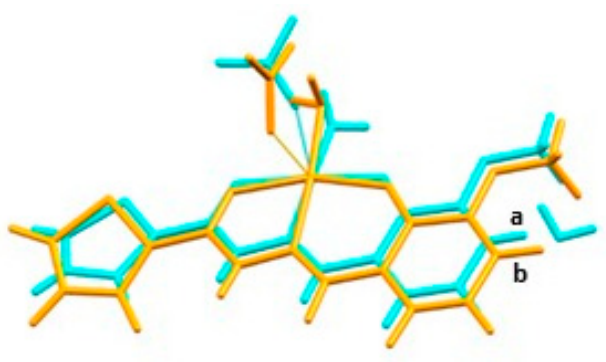

Figure 2. Comparison of the experimental (a) and calculated (b) geometries of CuHL. 


\subsection{Vibrational Spectroscopy}

FTIR and Raman spectra of solid samples of CuHL were recorded in the $4000-400 \mathrm{~cm}^{-1}$ frequency range and analyzed in comparison with those obtained for the free ligand $\mathrm{H}_{2} \mathrm{~L}$ [24] and are shown in Figure S2. Harmonic vibrational frequencies were also calculated at the DFT level of theory used for geometry optimization and were used to help in the assignment of experimental bands. No factors were used to scale the calculated frequencies. A complete table of vibrational spectroscopic results is available in the Supplementary Materials (Table S8).

The IR bands assigned to the $\mathrm{OH}$ group of the free ligand disappear in the spectrum of the complex, hence confirming the deprotonation of the phenolic oxygen and forward coordination of the phenoxide to the copper center.

According to the calculations, the $\mathrm{C}=\mathrm{O}$ and $\mathrm{C}=\mathrm{N}$ stretching modes are coupled, giving rise to a broad and intense band at $1606 \mathrm{~cm}^{-1}$ in the IR spectrum and to an intense Raman signal at $1618 \mathrm{~cm}^{-1}$, with a shoulder at $1603 \mathrm{~cm}^{-1}$. The presence of these signals, together with those due to the out-of-plane and in-plane $\mathrm{NH}$ bending, in the spectra of the complex is in accordance with the keto-amino tautomeric form of the coordinated ligand.

The shift to lower frequencies of the $v \mathrm{C}=\mathrm{O}$ band, located a $1640 \mathrm{~cm}^{-1}$ in the ligand spectrum, denotes the effect of the coordination of $\mathrm{Cu}(\mathrm{II})$ through the oxygen atom. The bands observed at 541 (IR) and $544 \mathrm{~cm}^{-1}$ (Raman), assigned to the $\mathrm{O}-\mathrm{Cu}-\mathrm{O}$ stretching, also confirm the coordination of the metal to the carbonyl group and to the phenoxide oxygen of the ligand. Two signals at 463 and $456 \mathrm{~cm}^{-1}$ in the IR spectrum were assigned to the $\mathrm{Cu}-\mathrm{O}$ (water) and $\mathrm{Cu}-\mathrm{N}$ (ligand) stretching modes, respectively. These values are in accordance with the calculated frequencies.

The strong band at $1561 \mathrm{~cm}^{-1}$ is assigned to the stretching of the $o$-VA ring coupled to the in-plane deformation of the $\mathrm{N}-\mathrm{H}$ group and is related to the weak Raman signal at $1565 \mathrm{~cm}^{-1}$. As expected, most vibrational modes of the rings in the ligand are not significantly affected, since they are not directly involved in the coordination.

Regarding the $\mathrm{NO}_{3}{ }^{-}$counterion, four main bands are expected at approximately 1390, 1050, 831 and $720 \mathrm{~cm}^{-1}$, which are assigned to the stretching and in- and out-of-plane deformation of the nitrate group [38]. In the spectrum of the complex, it was possible to find an intense band at $1384 \mathrm{~cm}^{-1}$ and another of lower intensity at $1057 \mathrm{~cm}^{-1}$. The other bands were difficult to identify due to their low intensity, as they can be overlapped by more intense signals related to $\mathrm{CH}$ bonds in the same region.

\subsection{EPR Spectroscopy}

The electron paramagnetic resonance (EPR) spectrum of a polycrystalline sample of $\mathrm{CuHL}$ recorded at $298 \mathrm{~K}$ is shown in Figure 3 together with its simulation.

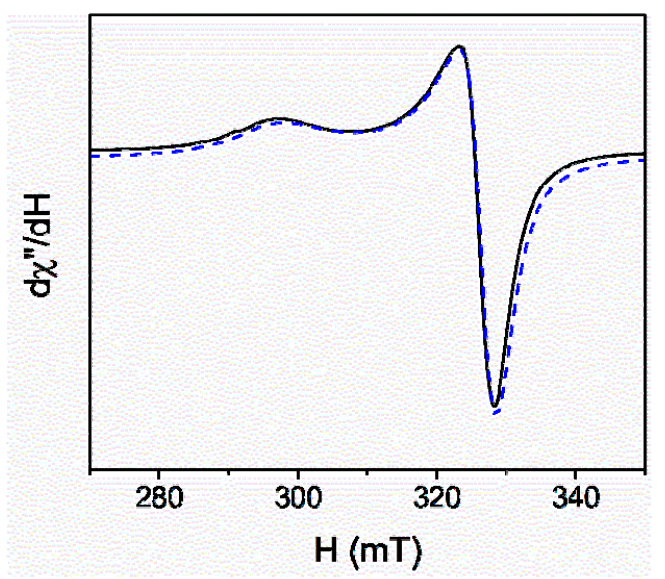

Figure 3. Electron paramagnetic resonance (EPR) spectrum of CuHL at $298 \mathrm{~K}(-)$ and the best fit $(----)$. 
The simulated spectrum is in accordance with an orthorhombic symmetry, with calculated $g$-tensor values of $g_{1}=2.273, g_{2}=2.068$ and $g_{3}=2.052$. The calculated $G$ value (Equation (1)) was 4.55, thus indicating that the exchange interactions between the paramagnetic centers are negligible [39] and, therefore, that the complex behaves as a monomeric species, as observed by XRD.

$$
G=\frac{g_{\|}-2}{g_{\perp}-2}
$$

Additionally, the $R$ parameter was obtained according to Equation (2), giving a value of 0.078 . This result suggests the predominance of a d $\left(x^{2}-y^{2}\right)$ ground state for the unpaired electron [40-43], in agreement with the geometry evidenced by the crystal structure.

$$
R=\frac{g_{2}-g_{1}}{g_{3}-g_{2}} \quad g_{3}>g_{2}>g_{1}
$$

\subsection{Electronic Spectroscopy}

The UV-Visible spectra of CuHL were recorded in dimethyl sulfoxide (DMSO) solution at $1 \times 10^{-4} \mathrm{M}$ and $1 \times 10^{-2} \mathrm{M}$ to selectively register bands with very different molar absorptivities. Spectra of both solutions were recorded several times for $72 \mathrm{~h}$ without significant changes, showing stability within this period. The absorption spectrum of a solid sample was also obtained by transformation with the Kubelka-Munk equation from the diffuse reflectance measurement [44]. The results are depicted in Figure 4 and are analyzed in comparison with the spectrum of the free ligand.

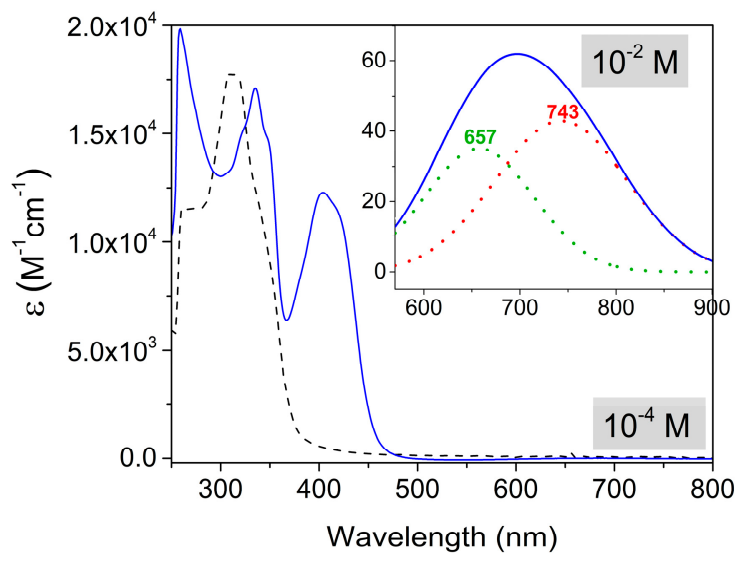

(a)

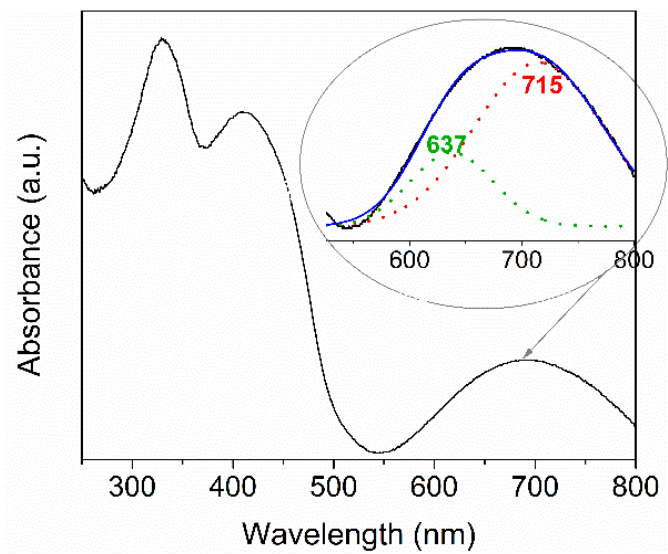

(b)

Figure 4. (a) Electronic spectra of CuHL (- ) and ligand (- - -) obtained for dimethyl sulfoxide (DMSO) solutions. A higher concentration was employed to register $\mathrm{d}-\mathrm{d}$ transitions and to analyze them by deconvolution ( . .). (b) Spectra obtained by diffuse reflectance of a solid sample.

The electronic spectrum of the complex was also calculated within the framework of time-dependent DFT (TD-DFT). The gas-phase-optimized geometry was used to that end, and solvent effects (DMSO) were considered implicitly through the COSMO model.

The spectra were deconvolved in the visible region and the position of the maxima along with the calculated values and the proposed assignment of the bands are listed in Table 3. Assignments were established from reported data of related complexes [5,8,45-47] and with the help of TD-DFT calculations. Molecular orbitals involved in the transitions are depicted in Figure S3. 
Table 3. Experimental and calculated electronic spectra of the complex in DMSO solution and solid sample. Band maximum and transition energies are given in $\mathrm{nm}$. The molar absorptivity (in $\mathrm{M}^{-1} \cdot \mathrm{cm}^{-1}$ ) and calculated oscillator strength (O.S.) (in atomic units) are in parentheses. The proposed assignment is also given.

\begin{tabular}{ccccc}
\hline $\begin{array}{c}\text { Experimental } \\
\text { in DMSO }\left(\boldsymbol{\varepsilon}, \mathbf{~ M}^{-\mathbf{1}} \cdot \mathbf{c m}^{-1}\right)\end{array}$ & $\begin{array}{c}\text { Experimental, } \\
\text { Solid Sample }\end{array}$ & $\begin{array}{c}\text { Calculated } \\
(\mathbf{O} \text {. S.) }\end{array}$ & Transition & Assignment \\
\hline $743(43)$ & $715^{* *}$ & $843(0.00023)$ & $\mathrm{H}_{\beta}-9 \rightarrow \mathrm{L}_{\beta}$ & $\mathrm{d} \rightarrow \mathrm{d}$ \\
$657(35)$ & $637^{* *}$ & $670(0.00040)$ & $\mathrm{H}_{\beta}-15 \rightarrow \mathrm{L}_{\beta}$ & $\mathrm{d} \rightarrow \mathrm{d}$ \\
& & $581(0.00129)$ & $\mathrm{H}_{\beta}-16 \rightarrow \mathrm{L}_{\beta}$ & $\mathrm{d} \rightarrow \mathrm{d}$ \\
$423(\mathrm{sh})$ & 411 & $573(0.00159)$ & $\mathrm{H}_{\beta}-17 \rightarrow \mathrm{L}_{\beta}$ & $\mathrm{d} \rightarrow \mathrm{d}$ \\
$404\left(1.2 \times 10^{4}\right)$ & & $478(0.10700)$ & $\mathrm{H}_{\beta} \rightarrow \mathrm{L}_{\beta}$ & $\mathrm{LMCT}$ \\
& & $438(0.00123)$ & $\mathrm{H}_{\beta}-1 \rightarrow \mathrm{L}_{\beta}$ & $\mathrm{LMCT}$ \\
$348(\mathrm{sh})$ & 330 & $345(0.30163)$ & $\mathrm{H}_{\alpha} \rightarrow \mathrm{L}_{\alpha}+1$ & Intraligand \\
$335\left(1.7 \times 10^{4}\right)$ & & $287(0.48728)$ & $\mathrm{H}_{\beta}-5 \rightarrow \mathrm{L}_{\beta}$ & LMCT \\
$320(\mathrm{sh})$ & & $264(0.10541)$ & $\mathrm{H}_{\alpha}-5 \rightarrow \mathrm{L}_{\alpha}$ & Intraligand \\
$258^{*}$ & & $246(0.02130)$ & $\mathrm{H}_{\alpha}-1 \rightarrow \mathrm{L}_{\alpha}+1$ & Intraligand \\
\hline
\end{tabular}

* Solvent cut off. ** Values obtained by deconvolution. ${ }^{(a)} \mathrm{H}$ and $\mathrm{L}$ are used as short notations for HOMO and LUMO, respectively, whereas $\alpha$ and $\alpha$ refer to the electronic spin channels. (sh): shoulder.

The calculations predicted four $\mathrm{d}-\mathrm{d}$ transitions at $843,670,581$ and $573 \mathrm{~nm}$. Two of them, at lower energy and assigned to $\mathrm{d}(\mathrm{xy}) \rightarrow \mathrm{d}\left(\mathrm{x}^{2}-\mathrm{y}^{2}\right)$ and $\mathrm{d}\left(\mathrm{z}^{2}\right) \rightarrow \mathrm{d}\left(\mathrm{x}^{2}-\mathrm{y}^{2}\right)$ transitions, are located at 657 and $743 \mathrm{~nm}$ following the deconvolution of the broad band, with a maximum near $700 \mathrm{~nm}$. The more energetic transitions $\left(d(y z) \rightarrow d\left(x^{2}-y^{2}\right)\right.$ and $\left.\mathrm{d}(\mathrm{xz}) \rightarrow \mathrm{d}\left(\mathrm{x}^{2}-\mathrm{y}^{2}\right)\right)$ are expected to give rise to closely located bands, which could not be distinguished by deconvolution and are probably overlapped with the more intense band with a maximum at $411 \mathrm{~nm}$, with a shoulder at approximately $423 \mathrm{~nm}$. Thus, the latter band can be assigned to both $\mathrm{d}-\mathrm{d}$ and ligand-to-metal charge transfer (LMCT) transitions. The discrepancies observed between the calculated and the experimental transition energies can be attributed to the small differences between the experimental and calculated bond lengths.

The spectrum recorded for the solid sample shows a similar behavior to that obtained for the solution. The differences in the maximum positions can be attributed to the intrinsic differences in the measurement techniques and the deconvolution process. Despite the possible interaction of the solvent, changes in the coordination geometry would have led to more significant changes in the spectra; thus, it can be inferred that there are no relevant changes in the coordination environment of $\mathrm{CuHL}$ from the solid to the DMSO solution.

By comparison with the free ligand spectrum and according to the calculations, the set of bands in the solution spectrum of the complex observed at 348, 335 and $320 \mathrm{~nm}$ and the corresponding broad band recorded for the solid sample at $330 \mathrm{~nm}$ are assigned to intraligand and LMCT transitions.

\subsection{Cell Viability Study}

Cell viability assays were performed for $\mathrm{H}_{2} \mathrm{~L}$ and CuHL with three tumor cell lines, namely MG-63 (human osteosarcoma), A549 (lung adenocarcinoma) and HT-29 (colorectal adenocarcinoma), and one non-tumor cell line, L929 (mouse-derived fibroblast).

Table 4 shows the $\mathrm{IC}_{50}$ values and the selectivity index (SI) of CuHL and the reference metallo-drug cisplatin (CDDP). As can be seen, the complex induced cytotoxicity on MG63, A549 and HT-29 from 1 to $8 \mu \mathrm{M}(p<0.01)$. Nevertheless, the compound only has a good selectivity on MG-63 $(\mathrm{SI}=1.8)$. On the other hand, the $\mathrm{IC}_{50}$ values of the free ligand and free metal cations are higher than $100 \mu \mathrm{M}$ for the three cell lines tested, hence revealing the key role of complexation to modulate the anti-cancer activity of this type of compound. This effect was described in many scientific reports for copper and other metal complexes $[48,49]$. 
Table 4. $\mathrm{IC}_{50}$ values $(\mu \mathrm{M})$ and selectivity index (SI) of CuHL and CDDP on MG-63, HT-29, A549 and L929 cell lines after $24 \mathrm{~h}$ of incubation.

\begin{tabular}{ccccc}
\hline Cell Lines & IC $_{5 \mathbf{0}}$ CuHL & SI CuHL & IC $_{\text {50 }}$ CDDP & SI CDDP \\
\hline MG-63 & $2.0 \pm 0.5$ & 1.8 & $39 \pm 1.8$ & 0.3 \\
HT-29 & $7.4 \pm 0.9$ & 0.5 & $178.8 \pm 4.9$ & 0.06 \\
A549 & $3.1 \pm 0.6$ & 1.2 & $114.0 \pm 2.3$ & 0.1 \\
L929 & $3.6 \pm 0.3$ & & $11.2 \pm 1.6$ & \\
\hline
\end{tabular}

With the aim to establish the anti-cancer potency of CuHL, its effects on cell viability were compared with those of the clinical reference CDDP on the cancer panel cell lines tested. As it can be seen in Table 5, the complex is significantly more cytotoxic than CDDP on all tested tumor cells. Besides, CuHL showed a remarkably stronger selectivity than CDDP on MG-63 cells (SI(CuHL) 1.8 vs. SI(CDDP) 0.3 *).

Table 5. Trolox equivalent antioxidant capacity (TEAC) values determined from the slope of the \% inhibition curve.

\begin{tabular}{ccc}
\hline Compound & $\mathbf{H}_{2} \mathbf{L}$ & CuHL \\
\hline TEAC & 1.33 & 0.24 \\
\hline
\end{tabular}

Our results indicate that the CuHL displayed a selective action on human bone cancer cells. Scientific reports showed that copper complexes with $\mathrm{IC}_{50}$ values in the low micromolar range $(<10 \mu \mathrm{M})$ have been recognized as potent cytotoxic agents against different human cancer cell lines [8]. In this sense, previous results of our group on a copper(II) complex with a tridentate ONO acylhydrazone ligand with benzene rings [50], showed higher $\mathrm{IC}_{50}$ values than $\mathrm{CuHL}$ for MG-63 $(8.8 \pm 0.3 \mu \mathrm{M})$ and A549 $(12 \pm 1.2 \mu \mathrm{M})$, hence suggesting that the thiophene ring may play some role in the anti-cancer activity of the metal complex. Besides, the biological effects of four $\mathrm{Cu}$ (II) complexes with Schiff base ligands on human colon carcinoma cells (HT-29) have been also investigated. All of them exhibited cytotoxic effects, with $\mathrm{IC}_{50}$ values between 0.6 to $31 \mu \mathrm{M}$ [50], and induced the mitochondria-dependent pathway of apoptosis [51]. Another Schiff base compound, $\mathrm{Cu}(\mathrm{BrHAP})_{2}$, demonstrated a potent anti-tumor effect in HT-29 cells $\left(\mathrm{IC}_{50}=2.87 \pm 0.2\right)$ and induced elevation of reactive oxygen species (ROS) production and activation of caspases 3/7 and 9 [52]. Furthermore, the synthesis of nine salicylaldehyde pyrazole hydrazone (SPH) derivatives and their corresponding copper complexes ( $\mathrm{Cu}-\mathrm{SPH}$ ) were reported. Cell viability studies showed that all the SPHs as well as $\mathrm{Cu}-\mathrm{SPH}$ had potent inhibitory effects on A549 cells. However, Cu-SPHs showed stronger growth-inhibitory effects $\left(\mathrm{IC}_{50}=1.87\right.$ to $\left.3.5 \mu \mathrm{M}\right)$ than their corresponding SPHs (3.5 to $\left.11 \mu \mathrm{M}\right)$, demonstrating the beneficial actions of complexation [53].

Finally, our previous results on an oxidovanadium(IV) complex with other thiophenes containing Schiff base ligands, showing a much higher $\mathrm{IC}_{50}$ value on MG-63 cells than $\mathrm{CuHL}$, demonstrate the importance of the nature and the environment geometry of the metal center in the effectiveness of metallo-drugs [54].

\subsection{Antioxidant Activity}

The antioxidant activity of the ligand and the complex was evaluated by the ABTS radical decoloration method. Figure 5 shows the inhibition of $\mathrm{ABTS}^{+\cdot}$ radical plots.

The antioxidant activity was calculated using Trolox as a reference antioxidant through the Trolox equivalent antioxidant capacity (TEAC) index. The values, obtained as described in the experimental section, are presented in Table 5. 
$\mathrm{y}=2.524 \mathrm{x}$
$\mathrm{H}_{2} \mathbf{L}$

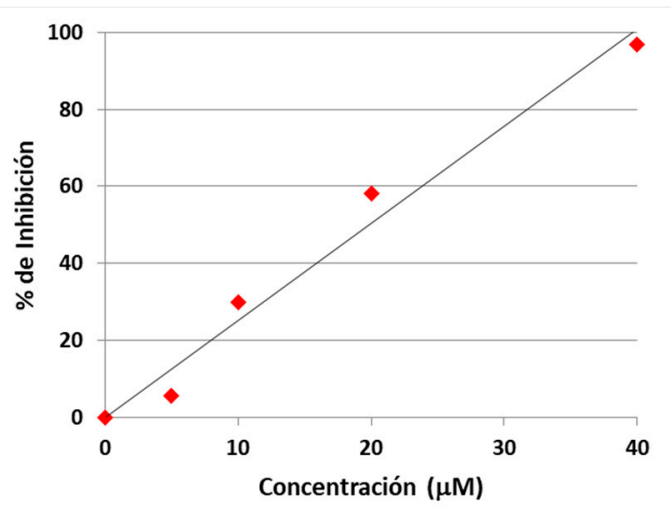

CuHL $\quad y=0.4296 x$

$\mathrm{R}^{2}=0.9705$

Figure 5. $\mathrm{ABTS}^{+\cdot}$ inhibition percentages for $\mathrm{H}_{2} \mathrm{~L}$ and $\mathrm{CuHL}$.

The TEAC values obtained for this method indicate that the ligand shows a slightly higher antioxidant activity than the reference compound Trolox, while the copper complex is not an efficient antioxidant agent. Figure 6 shows the percentage of ABTS $^{+\cdot}$ radicals remaining in the sample after the reaction with each compound at fixed concentrations, with $100 \%$ corresponding to the absence of any compound to be tested.

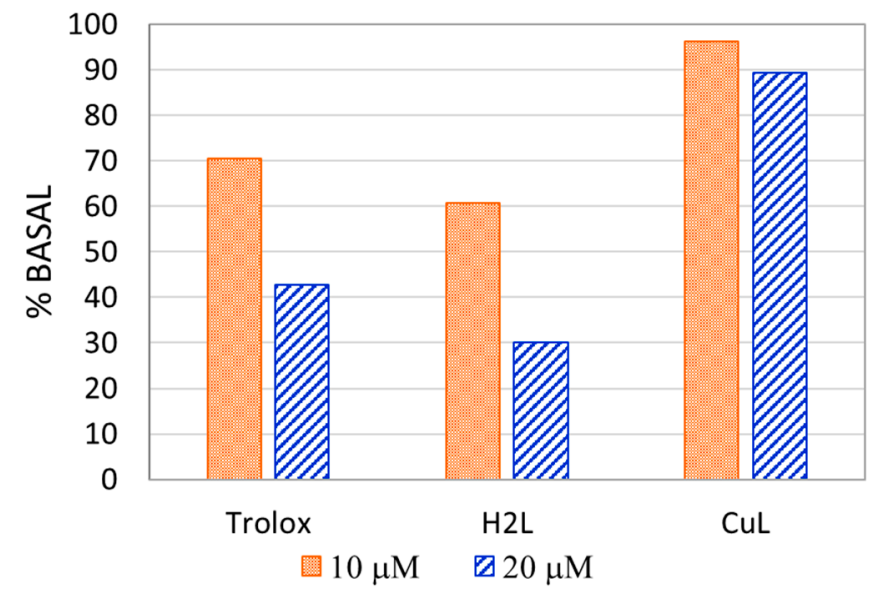

Figure 6. Antioxidant activity of each compound at different concentrations.

\section{Materials and Methods}

\subsection{Synthesis}

Absolute ethanol (Soria) and $\mathrm{Cu}\left(\mathrm{NO}_{3}\right)_{2} \cdot 2.5 \mathrm{H}_{2} \mathrm{O}$ (Riedel de Haën) were used as provided. The ligand $\mathrm{H}_{2} \mathrm{~L}$ was prepared from 2-thiophencarbohydrazide (TPNNH) and $o$-vanillin (o-HVA), according to the reported procedure [24]. The CuHL complex was prepared with addition of an ethanolic solution of $\mathrm{H}_{2} \mathrm{~L}(0.1476 \mathrm{~g}, 0.5 \mathrm{mmol}$ in $25 \mathrm{~mL})$ to $25 \mathrm{~mL}$ of a copper (II) penta-hemi-hydrate nitrate solution $(0.3772 \mathrm{~g}, 1.6 \mathrm{mmol})$ in the same solvent. The reaction was held under stirring and mild heating conditions for $30 \mathrm{~min}$ and a dark green solution was obtained. After approximately two months, dark green crystals of the complex were obtained. They were isolated by filtration and stored in a desiccator. Elemental analyses were performed using an Exeter CE 440 analyzer (Exeter Analytical, UK) and melting point was measured using a Bock monoscop " $\mathrm{M}$ " instrument. The solid decomposed at $179{ }^{\circ} \mathrm{C}$; thus, its melting point could not be determined (yield: $67 \%, 0.1462$ g). Anal. found: $\mathrm{C}, 35.9 \% ; \mathrm{H}, 3.4 \%$;, $10.1 \%$;, $7.3 \%$; calc. for $\mathrm{C}_{13} \mathrm{H}_{15} \mathrm{CuN}_{3} \mathrm{O}_{8} \mathrm{~S}$ : C, $35.7 \%$; H, 3.5\%; N, 9.6\%; S, 7.3\%. 


\subsection{X-ray Diffraction Data}

The X-ray diffraction data of CuHL were obtained from measurements on an Oxford Xcalibur Gemini, Eos CCD diffractometer with graphite monochromated CuK $\alpha$ $(\lambda=1.54178 \AA$ ) radiation (http:/ / www.agilent.com, Santa Clara, CA, United States). X-ray diffraction intensities were recorded ( $\omega$ scans with $\theta$ and $k$-offsets), integrated and scaled with CrysAlisPro [55] software (Oxford Diffraction Ltd, version 1.171.33.48). Unit cell parameters were obtained by least-squares refinement (based on the angular settings for all collected reflections with intensities larger than seven times the standard deviation of measurement errors) using CrysAlisPro. The data were corrected empirically by absorption, using the multi-scan method included in CrysAlisPro. The structure was solved by the intrinsic phasing procedure implemented in SHELXT [56] and the corresponding non- $\mathrm{H}$ molecular model refined with anisotropic displacement parameters with SHELXL [57]. The hydrogen atoms of the organic ligand were located at their expected geometrical positions and refined with the riding model. The methyl $\mathrm{H}$-atom positions were optimized by treating the $-\mathrm{CH}_{3}$ group as a rigid one allowed to rotate around the $\mathrm{O}-\mathrm{CH}_{3}$ bonds so as to maximize the sum of the electron densities at the calculated positions. The methyl group converged to a staggered angular conformation. The water H-atoms were located in a difference Fourier map and refined at their found positions, with isotropic displacement parameters and $\mathrm{Ow}-\mathrm{H}$ and $\mathrm{H} \ldots \mathrm{H}$ distances restrained to target values of $0.86(1)$ and 1.36(1) ̊, respectively.

Crystallographic structural data have been deposited at the Cambridge Crystallographic Data Centre (CCDC). Enquiries for data can be directed to the Cambridge Crystallographic Data Centre, 12 Union Road, Cambridge, UK, CB2 1EZ or (e-mail) deposit@ccdc.cam.ac.uk or (fax) +44 (0) 1223 336033. Any request to the Cambridge Crystallographic Data Centre for this material should quote the full literature citation and the reference number CCDC 2046671.

\subsection{Spectroscopy}

Infrared spectra of solid samples (KBr pellets) were recorded with a Bruker Equinox 55 instrument (Billerica, MA, United States) in the $4000-400 \mathrm{~cm}^{-1}$ region. Raman spectra were measured with a WITEC alpha 300 RA spectrophotometer (https:/ / www.witec.de/), using a laser excitation wavelength of $532 \mathrm{~nm}$ and a 20x objective lens.

Electronic spectra of the complex and ligand were measured using a Shimadzu UV2006 spectrophotometer (https:/ / www.shimadzu.com/). UV-Vis spectra were recorded in a solution of dimethyl sulfoxide (DMSO) using $10 \mathrm{~mm}$ quartz cells in the spectral range from 250 to $800 \mathrm{~nm}$. The diffuse reflectance spectrum of solid samples was recorded using a $\mathrm{BaSO}_{4}$ pellet as a reference with an integrating sphere attachment, in the $250-800 \mathrm{~nm}$ range, and it was forward-converted to absorbance using the Kubelka-Munk function [44].

X-band electron paramagnetic resonance spectra were measured on a polycrystalline sample of the complex in the 298-120 K range. A Bruker EMX spectrometer was used, equipped with a Bruker ER 036TM NMR-Tesla meter, an Agilent 53150A microwave frequency meter and a Bruker ER 4131VT accessory for the control of the variable temperature measurements. Simulations of the recorded spectra were carried out using the Simfonia Program (Version 1.25, Billerica, MA, United States) [58]. Experimental details of the data collection: modulation amplitude, $0.1 \mathrm{mT}$; time constant, $40.96 \mathrm{~ms}$; conversion time, $327.68 \mathrm{~ms}$; gain, $1 \times 10^{3}$; power, $20 \mathrm{~mW}$; and microwave frequency, $9.4258 \mathrm{GHz}$.

\subsection{Computational Methods}

The X-ray diffraction structure of CuHL was adopted as the starting geometry for the calculations. The geometry of the complex was optimized in the gas phase using the Becke's three parameters functional [59] with the correlation functional of Lee, Yang and Parr [60] (B3LYP), as implemented in the ORCA program (Version 3.0.3) [61]. The triple-zeta quality Def2-TZVP basis set [62] was used for all atoms. 
The eigenvalues of the Hessian matrix of the total energy with respect to nuclear coordinates were calculated to verify that the optimized geometries were local minima on the potential energy surface. The eigenvalues were then transformed to harmonic vibrational frequencies, which were further used to assist in the assignment of the experimental vibrational spectra. No scale factors were applied to the calculated frequencies.

Electronic spectrum calculations were also calculated by means of time-dependent DFT, using, in this case, the hybrid PBE0 [63] functional with the Def2-TZVP basis set. Solvation effects were included through the conductor-like screening model (COSMO) [64]. The results were used to help in the assignment of the experimental electronic spectra.

\subsection{Cell Viability Study: 3-(4,5-Dimethylthiazol-2-Yl)-2,5-Diphenyltetrazolium Bromide Assay}

Cell viability assays were performed for the complex $\mathrm{CuHL}$ and the ligand $\mathrm{H}_{2} \mathrm{~L}$ with three tumor cell lines, MG-63 (human osteosarcoma), A549 (lung adenocarcinoma) and HT-29 (colorectal adenocarcinoma), and one non-tumor cell line, L929 (mouse-derived fibroblast). All the cell lines were provided by American Type Culture Collection (ATCC).

The 3-(4,5-dimethylthiazol-2-yl)-2,5-diphenyltetrazolium bromide (MTT) assay was performed according to Mosmann [65]. Briefly, cells were seeded in a 96-well dish for $24 \mathrm{~h}$ and treated with different concentrations of compounds 1 and $2(1-50 \mu \mathrm{M})$ at $37^{\circ} \mathrm{C}$ for $24 \mathrm{~h}$. Then, the medium was changed, and the cells were incubated with $0.5 \mathrm{mg} / \mathrm{mL}$ MTT under normal culture conditions for $3 \mathrm{~h}$. Cell viability was marked by the conversion of the tetrazolium salt MTT to a colored formazan by mitochondrial dehydrogenases. Color development was measured spectrophotometrically with a microplate reader (model 7530, Cambridge Technology, USA) at $570 \mathrm{~nm}$ after cell lysis in DMSO (100 $\mu \mathrm{L}$ per well).

\section{Cell Line and Growth Conditions}

MG-63 (bone), A549 (lung) and HT-29 (colorectal) tumor cells and L929 non-tumoral cells were grown in Dulbecco's Modified Eagle's Medium (DMEM) containing 10\% 2,2' azinobis(3-ethylbenzothiazoline-6-sulfonic acid) diammonium salt (FBS), $100 \mathrm{U} / \mathrm{mL}$ penicillin and $100 \mu \mathrm{g} / \mathrm{mL}$ streptomycin at $37^{\circ} \mathrm{C}$ in a $5 \% \mathrm{CO}_{2}$ atmosphere. Cells were seeded in a $75-\mathrm{cm}^{2}$ flask, and cells were subcultured using $1 \mathrm{~mL}$ of TrypLE ${ }^{\mathrm{TM}}$. For experiments, cells were grown in multiwell plates. When cells reached the desired confluence, the monolayers were washed with PBS and were incubated under different conditions according to the experiments.

\subsection{Antioxidant Activity}

Antioxidant activity was evaluated using the ABTS method by determining the Trolox (6-hydroxy-2,5,7,8-tetramethylchroman-2-carboxylic acid) equivalent antioxidant coefficient (TEAC). The radical cation of 2,2'-azinobis(3-ethylbenzothiazoline-6-sulfonic acid) diammonium salt $\left(\mathrm{ABTS}^{+}\right)$was generated by incubating ABTS with potassium persulfate. The resultant solution was diluted in $0.1 \mathrm{M} \mathrm{KH}_{2} \mathrm{PO}_{4}-\mathrm{NaOH}$ buffer ( $\mathrm{pH} 7.4$ ) until an absorbance of approximately 0.7 at $734 \mathrm{~nm}$ [66].

The antioxidant activity of the compounds was determined by measuring the absorbance of a mixture of $990 \mu \mathrm{L}$ of the solution containing the radical and $10 \mu \mathrm{L}$ of solution of the tested compound (the complex, the ligand or Trolox standard) in DMSO to reach a final concentration in the range of $0-100 \mu \mathrm{M}$. The reduction of $\mathrm{ABTS}^{+\cdot}$ was monitored spectrophotometrically after $6 \mathrm{~min}$ of the initial mixing at $30^{\circ} \mathrm{C}$. Each determination was run in triplicate.

The percentage of inhibition at each concentration was calculated related to the absorbance of a reference solution without antioxidant sample, according to Equation (3).

$$
\% \text { inhibition }=\frac{\text { Abs }(\text { reference })-\text { Abs }(\text { sample })}{\text { Abs }(\text { reference })} \times 100
$$


The values are therefore plotted vs. concentration, and from the slope of the fitting line, the TEAC (Equation (4)) is calculated, thus indicating the concentration of Trolox with equivalent activity to the concentration unity of the analyzed compound.

$$
\mathrm{TEAC}=\frac{\text { slope }(\text { sample })}{\text { slope }(\text { Trolox })}
$$

\section{Conclusions}

By means of a straightforward synthetic procedure, crystals of a $\mathrm{Cu}(\mathrm{II})$ complex $(\mathrm{CuHL})$, with a hydrazone ligand derived from $o$-vanillin and a thiophene hydrazide $\left(\mathrm{H}_{2} \mathrm{~L}\right)$, were obtained. The coordination compound crystalizes in the triclinic $P-1$ space group as a cationic (+1) complex with a nitrate counterion. The metal is at the center of a nearly squared environment, coordinated by the deprotonated tridentate (ONO) ligand, $\mathrm{HL}^{-}$and a water molecule. The crystal structure was stabilized by H-bond interactions involving crystallization water molecules and the nitrate anion. The crystal is further stabilized by $\mathrm{H}$-bond interactions involving the water molecules, the amine, methoxy and carbonyl groups of the ligand and the nitrate counterion.

Its spectroscopic analyses in the solid state and in solution, including different techniques, were complemented by DFT calculations that supported the assignment of the vibrational and electronic spectra. The results are consistent with the tetracoordinated metal center and the tridentate deprotonated ligand in the keto-amino tautomeric form.

The complex was shown to be stable in DMSO solution for at least $72 \mathrm{~h}$, so biological assays of cytotoxic and antioxidant activity could be developed. It was proven to be a very good cytotoxic agent on MG-63, HT-29 and A549 tumor lines, remarkably improving the activity of the free ligand and also showing an $\mathrm{IC}_{50}$ value lower than those considered as promising agents in the literature. The results encourage continuation of the anti-tumor study through more specific assays.

Regarding the antioxidant activity, it did not show improvement of the results obtained for the free ligand, and the values obtained are not relevant.

Supplementary Materials: The following are available online at https:/ / www.mdpi.com/2304-674 0/9/2/9/s1, Table S1: Hydrogen bonds for CuHL; Table S2: Experimental bond distances of CuHL; Table S3: Experimental bond angles of CuHL; Table S4: Experimental dihedral angles of CuHL; Table S5: Calculated bond distances of CuHL; Table S6: Calculated bond angles of CuHL; Table S7: Calculated dihedral angles of CuHL; Table S8: Assignment of the vibrational spectra of CuHL and H2L ligand; Figure S1: Drawings of CuHL showing crystal packing; Figure S2: FTIR and Raman spectra of CuHL along with FTIR spectrum of H2L. Figure S3: Representation of OMs involved in the electronic transitions of CuHL, CIF file (reference number CCDC 204667) and check-CIF PDF file.

Author Contributions: Conceptualization: A.C.G.-B. and B.P.P.-C.; investigation, M.R.R. (synthesis, characterization and calculations), L.M.B. (cytotoxicity assays), R.P.-D. (DFT), J.G.-T. (EPR), G.A.E. and O.E.P. (XRD); formal analysis: B.P.P.-C., O.E.P., I.E.L., R.P.-D. and A.C.G.-B.; writing-original draft preparation, M.R.R., L.M.B. and A.C.G.-B.; writing-review and editing, A.C.G.-B., B.P.P.-C., I.E.L., R.P.-D. and O.E.P.; supervision, A.C.G.-B. and I.E.L., B.P.P.-C.; funding acquisition, A.C.G.-B., I.E.L., O.E.P., G.A.E., R.P.-D., and J.G.-T. All authors have read and agreed to the published version of the manuscript.

Funding: This research was funded by CONICET-CCT- La Plata (PIP 0651 and 034), ANPCyT (PICT 2016-1574) and UNLP (11/X041, 11/X837 and 11/X857), Argentina, and also by Consejería de Educación of Junta de Castilla y León BU022G18, Junta de Castilla y León and FEDER BU291P18 and BU049P20, Ministerio de Economía y Competitividad, CTQ2016-75023-C2-1-P, and Ministerio de Ciencia, Innovación y Universidades, CTQ(QMC) RED2018-102471-T, MultiMetDrugs Network (Spain).

Institutional Review Board Statement: Not applicable.

Informed Consent Statement: Not applicable.

Data Availability Statement: Not applicable. 
Acknowledgments: The authors thank David Ibáñez Martinez (Department of Chemistry, Universidad of Burgos, España) for Raman spectra measurements. O.E.P, G.A.E, R.P.-D., I.E.L., B.P.P.-C. and A.C.G.-B. are members of the Researcher Career of CONICET. J.G.-T. is member of the Department of Chemistry of the University of Burgos. M.R.R. is Post-doctoral Fellow and L.M.B. is Doctoral Fellow of CONICET.

Conflicts of Interest: The authors declare no conflict of interest.

\section{References}

1. Linder, M.C.; Hazegh-Azam, M. Copper biochemistry and molecular biology. Am. J. Clin. Nutr. 1996, 63, 797S-811S. [PubMed]

2. Crisponi, G.; Nurchi, V.M.; Fanni, D.; Gerosa, C.; Nemolato, S.; Faa, G. Copper-related diseases: From chemistry to molecular pathology. Coord. Chem. Rev. 2010, 254, 876-889. [CrossRef]

3. Peña, M.M.O.; Lee, J.; Thiele, D.J. A Delicate Balance: Homeostatic Control of Copper Uptake and Distribution. J. Nutr. 1999, 129, 1251-1260. [CrossRef] [PubMed]

4. Ali, I.; Mahmood, L.M.A.; Mehdar, Y.T.H.; Aboul-Enein, H.Y.; Said, M.A. Synthesis, characterization, simulation, DNA binding and anticancer activities of $\mathrm{Co}(\mathrm{II}), \mathrm{Cu}(\mathrm{II}), \mathrm{Ni}(\mathrm{II})$ and $\mathrm{Zn}(\mathrm{II})$ complexes of a Schiff base containing $o$-hydroxyl group nitrogen ligand. Inorg. Chem. Commun. 2020, 118, 108004. [CrossRef]

5. Gündüzalp, A.B.; Özsen, I.; Alyar, H.; Alyar, S.; Özbek, N. Biologically active Schiff bases containing thiophene/furan ring and their copper(II) complexes: Synthesis, spectral, nonlinear optical and density functional studies. J. Mol. Struct. 2016, 1120, 259-266. [CrossRef]

6. Puszko, A.; Krojcer, A.; Pełczynska, M.; Wietrzyk, J.; Cieślak-Golonka, M.; Jezierska, J.; Adach, A.; Kubiak, M. Mononuclear copper(II) nitrato complexes with methyl-substituted 4-nitropyridine $N$-oxide. Physicochemical and cytotoxic characteristics. J. Inorg. Biochem. 2010, 104, 153-160. [CrossRef]

7. Syamal, A.; Maurya, M.R.; Dooms, E.; McLean, J.A. Synthesis and Characterization of Nickel (II), Cobalt (II), Copper(II), Manganese (II), Zinc (II), Zirconium (IV), Oxomolybdenum (V), and Dioxouranium (VI) Complexes of the Schiff Base Derived from Salycylaldehyde and Thiophene-2-Carboxylic Acid Hydrazide. Synth. React. Inorg. Met. Chem. 1986, 16, 39-60. [CrossRef]

8. Santini, C.; Pellei, M.; Gandin, V.; Porchia, M.; Tisato, F.; Marzano, C. Advances in copper complexes as anticancer agents. Chem. Rev. 2014, 114, 815-862. [CrossRef]

9. Weder, J.E.; Dillon, C.T.; Hambley, T.W.; Kennedy, B.J.; Lay, P.A.; Biffin, J.R.; Regtop, H.L.; Davies, N.M. Copper Complexes of Non-Steroidal Anti-Inflammatory Drugs: An Opportunity Yet to Be Realized. Coord. Chem. Rev. 2002, 223, 95-126. [CrossRef]

10. Rodríguez-Argüelles, M.C.; Mosquera-Vázquez, S.; Tourón-Touceda, P.; Sanmartín-Matalobos, J.; García-Deibe, A.M.; BelicchiFerrari, M.; Pelosi, G.; Pelizzi, C.; Zani, F. Complexes of 2-thiophenecarbonyl and isonicotinoyl hydrazones of 3-( $N$-methyl)isatin. A study of their antimicrobial activity. J. Inorg. Biochem. 2007, 101, 138-147. [CrossRef]

11. Anitha, C.; Sheela, C.D.; Tharmaraj, P.; Johnson Raja, S. Synthesis and characterization of VO(II), Co(II), Ni(II), Cu(II) and Zn(II) complexes of chromone based azo-linked Schiff base ligand. Spectrochim. Acta Part A Mol. Biomol. Spectrosc. 2012, 98, 35-42. [CrossRef] [PubMed]

12. Liu, X.; Manzur, C.; Novoa, N.; Celedón, S.; Carrillo, D.; Hamon, J.R. Multidentate unsymmetrically-substituted Schiff bases and their metal complexes: Synthesis, functional materials properties, and applications to catalysis. Coord. Chem. Rev. 2018, 357, 144-172. [CrossRef]

13. Da Silva, C.M.; Da Silva, D.L.; Modolo, L.V.; Alves, R.B.; De Resende, M.A.; Martins, C.V.B.; De Fátima, Â. Schiff bases: A short review of their antimicrobial activities. J. Adv. Res. 2011, 2, 1-8. [CrossRef]

14. Kajal, A.; Bala, S.; Kamboj, S.; Sharma, N.; Saini, V. Schiff Bases: A Versatile Pharmacophore. J. Catal. 2013, 2013, 1-14. [CrossRef]

15. Desai, S.B.; Desai, P.B.; Desai, K.R. Syntheses of some Schiff bases, thiazolididones and azetidinones derived from 2,6diaminobenzo[1,2-d:4,5-d'] bisthiazole and their anticancer activities. Heterocycl. Commun. 2001, 7. [CrossRef]

16. Jarrahpour, A.; Motamedifar, M.; Pakshir, K.; Hadi, N.; Zarei, M. Synthesis of Novel Azo Schiff Bases and Their Antibacterial and Antifungal Activities. Molecules 2004, 9, 815-824. [CrossRef]

17. Hearn, M.J.; Cynamon, M.H.; Chen, M.F.; Coppins, R.; Davis, J.; Joo-On Kang, H.; Noble, A.; Tu-Sekine, B.; Terrot, M.S.; Trombino, D.; et al. Preparation and antitubercular activities in vitro and in vivo of novel Schiff bases of isoniazid. Eur. J. Med. Chem. 2009, 44, 4169-4178. [CrossRef]

18. Zhang, H.J.; Qin, X.; Liu, K.; Zhu, D.D.; Wang, X.M.; Zhu, H.L. Synthesis, antibacterial activities and molecular docking studies of Schiff bases derived from $N$-(2/4-benzaldehyde-amino) phenyl- $N^{\prime}$-phenyl-thiourea. Bioorganic Med. Chem. 2011, 19, $5708-5715$. [CrossRef]

19. Hameed, A.; al-Rashida, M.; Uroos, M.; Abid Ali, S.; Khan, K.M. Schiff bases in medicinal chemistry: A patent review (2010-2015). Expert Opin. Ther. Pat. 2017, 27, 63-79. [CrossRef]

20. Przybylski, P.; Huczynski, A.; Pyta, K.; Brzezinski, B.; Bartl, F. Biological Properties of Schiff Bases and Azo Derivatives of Phenols. Curr. Org. Chem. 2009, 13, 124-148. [CrossRef]

21. Nogueira, L.; Cardoso, D.F.; Cristina, T.; Nogueira, M.; Kaiser, C.R.; Wardell, J.L.; Maria, S.; Veloso, S.; Vinicius, M.; Souza, N. De Synthesis and anti-tubercular activity of Thienyl and Furanyl derivatives. Mediterr. J. Chem. 2016, 5, 356-366.

22. Mohareb, R.M.; Fleita, D.H.; Sakka, O.K. Novel synthesis of hydrazide-hydrazone derivatives and their utilization in the synthesis of coumarin, pyridine, thiazole and thiophene derivatives with antitumor activity. Molecules 2011, 16, 16-27. [CrossRef] [PubMed] 
23. González-Baró, A.C.; Pis-Diez, R.; Parajón-Costa, B.S.; Rey, N.A. Spectroscopic and theoretical study of the $o$-vanillin hydrazone of the mycobactericidal drug isoniazid. J. Mol. Struct. 2012, 1007, 95-101. [CrossRef]

24. Rodríguez, M.R.; Del Plá, J.; Piro, O.E.; Echeverría, G.A.; Espino, G.; Pis-Diez, R.; Parajón-Costa, B.S.; González-Baró, A.C. Structure, tautomerism, spectroscopic and DFT study of $o$-vanillin derived Schiff bases containing thiophene ring. J. Mol. Struct. 2018, 1165, 381-390. [CrossRef]

25. Mohamed, G.G.; Sharaby, C.M. Metal complexes of Schiff base derived from sulphametrole and $o$-vanilin. Synthesis, spectral, thermal characterization and biological activity. Spectrochim. Acta Part A Mol. Biomol. Spectrosc. 2007, 66, 949-958. [CrossRef] [PubMed]

26. Yu, Y.-Y.; Xian, H.-D.; Liu, J.-F.; Zhao, G.-L. Synthesis, Characterization, Crystal Structure and Antibacterial Activities of Transition Metal(II) Complexes of the Schiff Base 2-[(4-Methylphenylimino)methyl]-6-methoxyphenol. Molecules 2009, 14, 1747-1754. [CrossRef]

27. Mishra, R.; Jha, K.K.; Kumar, S.; Tomer, I. Synthesis, properties and biological activity of thiophene: A review. Pharma Chem. 2011, 3, 38-54.

28. Malik, M.A.; Dar, O.A.; Gull, P.; Wani, M.Y.; Hashmi, A.A. Heterocyclic Schiff base transition metal complexes in antimicrobial and anticancer chemotherapy. Medchemcomm 2018, 9, 409-436. [CrossRef]

29. Forsch, R.A.; Wright, J.E.; Rosowsky, A. Synthesis and In Vitro Antitumor Activity of Thiophene Analogues of 5-Chloro-5,8dideazafolic Acid and 2-methyl-2-desamino-5-chloro-5,8-dideazafolic acid. Bioorg. Med. Chem. 2002, 10, 2067-2076. [CrossRef]

30. Cardoso, L.; Nogueira, T.; Rodrigues, F.; Oliveira, A.; Dos Santos Luciano, C.; Pessoa, C.; De Souza, M. CHEMISTRY Nacylhydrazones containing thiophene nucleus: A new anticancer class. Med. Chem. Res. 2017, 1-4. [CrossRef]

31. Molvi, K.I.; Vasu, K.K.; Yerande, S.G.; Sudarsanam, V.; Haque, N. Syntheses of new tetrasubstituted thiophenes as novel anti-inflammatory agents. Eur. J. Med. Chem. 2007, 42, 1049-1058. [CrossRef]

32. Jha, K.; Kumar, S.; Tomer, I.; Mishra, R. Thiophene: The molecule of diverse medicinal importance. J. Pharm. Res 2012, 5, 560-566.

33. Duffy, J.L.; Kirk, B.A.; Konteatis, Z.; Campbell, E.L.; Liang, R.; Brady, E.J.; Candelore, M.R.; Ding, V.D.H.; Jiang, G.; Liu, F.; et al. Discovery and investigation of a novel class of thiophene-derived antagonists of the human glucagon receptor. Bioorg. Med. Chem. Lett. 2005, 15, 1401-1405. [CrossRef]

34. Wardakhan, W.W.; Abdel-Salam, O.M.E.; Elmegeed, G.A. Screening for antidepressant, sedative and analgesic activities of novel fused thiophene derivatives. Acta Pharm. 2008, 58, 1-14. [CrossRef]

35. El-Salam, O.I.A.; Shalaby, A.M.; El-Sawy, A.A.; Elshihaby, S.; Abdulla, M. Synthesis of Some N-[(4-Substituted-1-Piperazinyl)Oxo(Alkyl and Ethylcarbamoyl)]-3-(2-Thiophenyl)Acrylamides as Non-Steroidal Anti-Allergic and Anti-Inflammatory Agents. Open J. Synth. Theory Appl. 2013, 2, 63-72. [CrossRef]

36. Fadda, A.A.; Berghot, M.A.; Amer, F.A.; Badawy, D.S.; Bayoumy, N.M. Synthesis and antioxidant and antitumor activity of novel pyridine, chromene, thiophene and thiazole derivatives. Arch. Pharm. (Weinh.) 2012, 345, 378-385. [CrossRef]

37. Farrugia, L.J. ORTEP-3 for Windows-A version of ORTEP-III with a Graphical User Interface (GUI). J. Appl. Crystallogr. 1997, 30, 565-566. [CrossRef]

38. Addison, C.C.; Gatehouse, B.M. The infrared spectra of anhydrous transition-metal nitrates. J. Chem. Soc. 1960, 613. [CrossRef]

39. Hathaway, B.J.; Billing, D.E. The electronic properties and stereochemistry of mono-nuclear complexes of the copper(II) ion. Coord. Chem. Rev. 1970, 5, 143-207. [CrossRef]

40. Garribba, E.; Micera, G. The Determination of the Geometry of Cu(II) Complexes: An EPR Spectroscopy Experiment. J. Chem. Educ. 2006, 83, 1229. [CrossRef]

41. González-Álvarez, M.; Alzuet, G.; Borrás, J.; Agudo, L.D.C.; García-Granda, S.; Montejo-Bernardo, J.M. Comparison of protective effects against reactive oxygen species of mononuclear and dinuclear $\mathrm{Cu}(\mathrm{II})$ Complexes with $\mathrm{N}$-substituted benzothiazolesulfonamides. Inorg. Chem. 2005, 44, 9424-9433. [CrossRef] [PubMed]

42. Billing, D.E.; Dudley, R.J.; Hathaway, B.J.; Tomlinson, A.A.G. Single-Crystal Electronic and Electron Spin Resonance Spectra of Di-chloroaquo-(2,9-dimethyl-1,10-phenanthroline)copper(II). J. Chem. Soc. 1971, 691-696. [CrossRef]

43. Hathaway, B.J. The correlation of the electronic properties and stereochemistry of mononuclear $\{\mathrm{CuN} 4-6\}$ chromophores. J. Chem. Soc. Dalt. Trans. 1972, 1196-1199. [CrossRef]

44. Kortum, G. Reflectance Spectroscopy Principles, Methods, Applications; Springer: New York, NY, USA, 1969 ; ISBN 3642880711.

45. Mei, Y.; Zhang, S.; Hu, C.; Zhang, J.; Yang, M. Synthesis, characterization, and crystal structures of mononuclear and dinuclear copper(II) complexes derived from similar tridentate Schiff bases. Inorg. Nano-Met. Chem. 2017, 47, 1270-1274. [CrossRef]

46. Jayendran, M.; Begum, P.M.S.; Kurup, M.R.P. Structural, spectral and biological investigations on Cu(II) and Zn(II) complexes derived from NNO donor tridentate Schiff base: Crystal structure of a 1D Cu(II) coordination polymer. J. Mol. Struct. 2020, 1206, 127682. [CrossRef]

47. Bhunia, A.; Vojtíšek, P.; Bertolasi, V.; Manna, S.C. Tridentate Schiff base coordinated trigonal bipyramidal/square pyramidal copper(II) complexes: Synthesis, crystal structure, DFT/TD-DFT calculation, catecholase activity and DNA binding. J. Mol. Struct. 2019, 1189, 94-101. [CrossRef]

48. Benítez, J.; Guggeri, L.; Tomaz, I.; Pessoa, J.C.; Moreno, V.; Lorenzo, J.; Avilés, F.X.; Garat, B.; Gambino, D. A novel vanadyl complex with a polypyridyl DNA intercalator as ligand: A potential anti-protozoa and anti-tumor agent. J. Inorg. Biochem. 2009, 103, 1386-1394. [CrossRef] 
49. Leon, I.E.; Di Virgilio, A.L.; Porro, V.; Muglia, C.I.; Naso, L.G.; Williams, P.A.; Bollati-Fogolin, M.; Etcheverry, S.B. Antitumor properties of a vanadyl(IV) complex with the flavonoid chrysin [VO(chrysin) $\left.{ }_{2} \mathrm{EtOH}\right]_{2}$ in a human osteosarcoma model: The role of oxidative stress and apoptosis. Dalton Trans. 2013, 42, 11868-11880. [CrossRef]

50. Burgos-Lopez, Y.; Del Plá, J.; Balsa, L.M.; León, I.E.; Echeverría, G.A.; Piro, O.E.; García-Tojal, J.; Pis-Diez, R.; González-Baró, A.C.; Parajón-Costa, B.S. Synthesis, crystal structure and cytotoxicity assays of a copper(II) nitrate complex with a tridentate ONO acylhydrazone ligand. Spectroscopic and theoretical studies of the complex and its ligand. Inorg. Chim. Acta 2019, 487, 31-40. [CrossRef]

51. Koňariková, K.; Perdikaris, G.A.; Gbelcová, H.; Andrezálová, L.; Švéda, M.; Ruml, T.; Laubertová, L.; Žitňanová, I. Effect of Schiff base $\mathrm{Cu}(\mathrm{II})$ complexes on signaling pathways in HT-29 cells. Mol. Med. Rep. 2016, 14, 4436-4444. [CrossRef]

52. Hajrezaie, M.; Paydar, M.; Zorofchian Moghadamtousi, S.; Hassandarvish, P.; Gwaram, N.S.; Zahedifard, M.; Rouhollahi, E.; Karimian, H.; Looi, C.Y.; Ali, H.M.; et al. A Schiff Base-Derived Copper (II) Complex Is a Potent Inducer of Apoptosis in Colon Cancer Cells by Activating the Intrinsic Pathway. Sci. World J. 2014, 2014, 1-12. [CrossRef] [PubMed]

53. Fan, C.D.; Su, H.; Zhao, J.; Zhao, B.X.; Zhang, S.L.; Miao, J.Y. A novel copper complex of salicylaldehyde pyrazole hydrazone induces apoptosis through up-regulating integrin $\beta 4$ in H322 lung carcinoma cells. Eur. J. Med. Chem. 2010, 45, 1438-1446. [CrossRef] [PubMed]

54. Rodríguez, M.R.; Balsa, L.M.; Del Plá, J.; García-Tojal, J.; Pis-Diez, R.; Parajón-Costa, B.S.; León, I.E.; González-Baró, A.C. Synthesis, characterization, DFT calculations and anticancer activity of a new oxidovanadium(IV) complex with a ligand derived from $o$-vanillin and thiophene. New J. Chem. 2019, 43, 11784-11794. [CrossRef]

55. CrysAlisPro, Oxford Diffraction Ltd, version 1.171.33.48 (release 15-09-2009 CrysAlis171.NET); Oxford Diffraction Ltd: Abingdon-onThames, UK, 2009.

56. Sheldrick, G.M. SHELXT-Integrated space-group and crystal-structure determination. Acta Crystallogr. Sect. A Found. Crystallogr. 2015, 71, 3-8. [CrossRef]

57. Sheldrick, G.M. A short history of SHELX. Acta Crystallogr. Sect. A Found. Crystallogr. 2008, 64, 112-122. [CrossRef]

58. WinEPR SimFonia, Version 1.25; Bruker Analytische Messtechnik GmbH: Billerica, MA, USA, 1996.

59. Yanai, T.; Tew, D.P.; Handy, N.C. A new hybrid exchange-correlation functional using the Coulomb-attenuating method (CAMB3LYP). Chem. Phys. Lett. 2004, 393, 51-57. [CrossRef]

60. Lee, C.; Yang, W.; Parr, R.G. Development of the Colle-Salvetti correlation-energy formula into a functional of the electron density. Phys. Rev. B 1988, 37, 785-789. [CrossRef]

61. Neese, F. The ORCA program system. Wiley Interdiscip. Rev. Comput. Mol. Sci. 2012, 2, 73-78. [CrossRef]

62. Weigend, F.; Ahlrichs, R. Balanced basis sets of split valence, triple zeta valence and quadruple zeta valence quality for $\mathrm{H}$ to Rn: Design and assessment of accuracy. Phys. Chem. Chem. Phys. 2005, 7, 3297-3305. [CrossRef]

63. Adamo, C.; Barone, V. Toward reliable density functional methods without adjustable parameters: The PBE0 model. J. Chem. Phys. 1999, 110, 6158-6170. [CrossRef]

64. Klamt, A.; Schüürmann, G. COSMO: A new approach to dielectric screening in solvents with explicit expressions for the screening energy and its gradient. J. Chem. Soc. Perkin Trans. 1993, 799-805. [CrossRef]

65. Mosmann, T. Rapid colorimetric assay for cellular growth and survival: Application to proliferation and cytotoxicity assays. J. Immunol. Methods 1983, 65, 55-63. [CrossRef]

66. Re, R.; Pellegrini, N.; Proteggente, A.; Pannala, A.; Yang, M.; Rice-Evans, C. Antioxidant Activity Applying An Improved ABTS Radical Cation Decolorization Assay. Free Radic. Biol. Med. 1999, 26, 1231-1237. [CrossRef] 